\title{
EEG AWAL TERAPI SEBAGAI PREDIKTOR KEKAMBUHAN PADA PENDERITA EPILEPSI YANG MENDAPAT TERAPI OBAT ANTIEPILEPSI
}

\section{EEG IN FIRST THERAPY AS PREDICTOR RELAPSE AT EPILEPSY PATIENT WITH ANTIEPILEPTIC DRUGS THERAPY}

\author{
Iwan Setiawan*, Harsono**, Ahmad Asmedi** \\ *Fakultas Kedokteran Universitas Muhammadiyah, Surakarta \\ **Fakultas Kedokteran Universitas Gajah Mada, Yogyakarta \\ Korespondensi: Iwan Setiawan, Email: ee onesetiawan@yahoo.co.id
}

\begin{abstract}
ABSTRAK
Epilepsi merupakan problem kesehatan yang penting di negara berkembang termasuk Indonesia. Faktor prediktor yang penting dalam meningkatkan kekambuhan bangkitan, diantaranya gambaran EEG abnormal. Nilai EEG sebagai prediktor kekambuhan pada penderita epilepsi masih kontroversi. EEG dengan spike wave yang persisten pada epilepsi umum primer, menunjukkan peluang yang tinggi terjadinya kekambuhan. Tujuan penelitian ini adalah mengukur besar peran EEG di awal terapi sebagai prediktor prognosis kekambuhan bangkitan pada pasien yang mendapat terapi obat anti-epilepsi secara teratur. Penelitian ini merupakan penelitian historikal kohort yang melibatkan 104 penderita epilepsi yang datang kontrol ke poliklinik saraf RS dr.Sardjito, Jogjakarta, dari januari 2006 sampai maret 2006. Dari analisis univariat didapatkan risiko relatif EEG RR: 1,957 (95\% CI, 1,3572,822). Hasil yang bermakna sebagai prediktor kekambuhan adalah gambaran EEG dengan tingkat kemaknaan $\mathrm{P}<0,05$. Kesimpulan dari penelitian ini adalah gambaran EEG abnormal merupakan prediktor kekambuhan pada penderita epilepsi yang mendapat terapi obat antiepilepsi, dengan risiko relatif 1,957.
\end{abstract}

Kata kunci: elektroensefalografi, epilepsi, prognosis, kekambuhan

\section{ABSTRACT}

Epilepsy was important health problem in development country including Indonesia. Important predictor factor that increasing risk of seizure recurrence was age of onset, secondary epilepsy and abnormalities EEG feature. The persistence of spike wave in those primary generalized epilepsy, indicating a higher chance of relapse. The value of EEG in predicting outcome is still controversial. EEG with spike wave persisten in primary general epilepsy, show tall opportunity the happening of relapse. The objective of this research was to quantify role of EEG feature as prognosis of relapse epilepsy in patient who get continous anti-epileptic drugs. The cohort retrospective study was conducted during outpatient epilepsy treatment at neurological clinic Sardjito hospital. From univariat analysis got relative risk as follows EEG RR: 1,957 (95\% CI 1,357-2,822). Result that have a meaning as predictor relapse description eeg with level significant $p<0,05$. Description EEG abnormal be predictor relapse in epilepsy sufferer that get drug therapy antiepilepsi, with relative risk 1,957.

Keyword: electroencephalography, epilepsy, prognosis, relapse

\section{PENDAHULUAN}

Epilepsi merupakan salah satu penyakit neurologis yang utama. Epilepsi sering dihubungkan dengan disabilitas fisik, disabilitas mental, dan konsekuensi psikososial yang berat bagi penderitanya (WHR, 2001). Diperkirakan di Indonesia yang berpenduduk sekitar 180 juta orang (220,5 juta orang menurut population data sheet tahun 2003), sekurang-kurangnya terdapat $900.000-1.800 .000$ orang penyandang epilepsi, sedangkan insiden adalah 90.000 kasus epilepsi baru tiap tahun (Mardjono, 1996). Angka prevalensi epilepsi pada umumnya berkisar antara 5-10 per 1000 orang penduduk (Kaiser et al, 1998).

Prognosis epilepsi dihubungkan dengan terjadinya remisi bangkitan baik dengan pengobatan maupun tidak, status psikososial, dan status neurologis penderita (Dreifuss, 1994). Pengetahuan tentang prognosis akan sangat 
berguna untuk pemberian informasi yang adekuat pada penderita epilepsi dan keluarganya, serta membantu dalam pengambilan keputusan medis (Sacket, 2001).

PeranEEG dalam memprediksikekambuhan setelah penghentian obat anti epilepsi masih kontroversial, beberapa penelitian menunjukkan adanya peningkatan angka kekambuhan dengan EEG abnormal pada awal dan selama penghentian obat (Sundaram et al, 1999). Dalam suatu Metaanalisis yang dilakukan Berg dan Shinnar (1994), disebutkan adanya hubungan antara abnormalitas EEG dengan peningkatan risiko kekambuhan pada penderita epilepsi anak maupun dewasa, dengan risiko relatif 1,45 (95\% CI, 1,18-1,79).

Tujuan penulisan makalah ini adalah untuk mengungkapkan besar peran gambaran EEG sebagai prediktor prognosis kekambuhan bangkitan epilepsi pada penderita yang mendapat terapi obat antiepilepsi. Masing-masing faktor prediktor prognosis akan dihitung risiko relatif untuk terjadinya kekambuhan bangkitan epilepsi.

Gambaran EEG yang abnormal berperan pula sebagai prediktor terjadinya kekambuhan. Penelitian yang dilakukan oleh Andersson et al. (1997) menunjukkan bahwa risiko kekambuhan akan meningkat 2,03 kali $(\mathrm{p}<0,01)$ pada penderita epilepsi anak-anak yang menunjukkan adanya gambaran aktivitas epileptiform pada rekaman EEG pertama dibanding yang tidak. Penelitian lain yang dilakukan oleh Lamdhade dan Taori (2002) terhadap 531 penderita epilepsi yang telah remisi menunjukkan bahwa gambaran EEG merupakan faktor prediktor relaps yang signifikan.

\section{METODE}

Penelitian ini merupakan penelitian mengenai prognosis, yang menggunakan rancangan penelitian kohort retrospektif atau kohort historikal. Penderita epilepsi yang masih teratur mendapat terapi obat antiepilepsi ditelusuri riwayat perjalanan bangkitannya, melalui wawancara maupun catatan medik. Gambaran EEG pada awal pengobatannya dan kejadian kekambuhannya dicatat dan kemudian dianalisis.

Subjek pada penelitian ini adalah semua penderita epilepsi yang datang di poliklinik Saraf RS Z Yogyakarta dan masih dalam pengobatan dengan obat antiepilepsi. Penelusuran data gambaran EEG pada awal terapi dilihat melalui catatan medik dan data mengenai perjalanan kekambuhan dikumpulkan melalui wawancara langsung baik pada penderita maupun keluarga penderita. Kriteria inklusi subjek penelitian ini adalah: 1) penderita epilepsi yang datang di poliklinik saraf, 2) mendapat terapi obat antiepilepsi secara rutin dan telah dilakukan pemeriksaan EEG awal/selama pengobatan, 3) pernah bebas bangkitan sedikitnya 6 bulan setelah terapi rutin, 4) catatan medik lengkap termasuk hasil rekaman EEG, sedangkan kriteria eksklusi adalah: 1) defisit neurologis berat seperti Retardasi mental, cerebral palsy, 2) menolak ikut dalam penelitian.

\section{HASIL DAN PEMBAHASAN}

Tabel 1 Karakteristik dasar subjek

\begin{tabular}{lcc}
\hline \multicolumn{1}{c}{ Variabel } & Jumlah & Persentase \\
\hline Jenis kelamin: Laki-laki & 54 & 51,9 \\
Perempuan & 50 & 48,1 \\
\cline { 1 - 2 } Rerata lama terapi (th) & 6,8 & \\
\cline { 1 - 2 } Umur awitan: rerata (th) & 24,5 & \\
Awitan anak (1-12 tahun) & 16 & 15,4 \\
Awitan dewasa (diatas 12 tahun) & 88 & 84,6 \\
\hline Etiologi: idiopatik & 74 & 71,2 \\
Simptomatik & 30 & 28,8 \\
\hline Jenis terapi: Monoterapi & 61 & 58,7 \\
Politerapi & 43 & 41,3 \\
\hline Kambuh: ya & 70 & 67,3 \\
Tidak & 34 & 32,7 \\
\hline Riwayat kejang demam/KD $(+)$ & 17 & 16,3 \\
Tidak ada KD & 87 & 83,7
\end{tabular}




\begin{tabular}{lcc}
\hline Riwayat keluarga (+) & 3 & 2,9 \\
Riwayat keluarga (-) & 101 & 97,1 \\
\cline { 1 - 1 } Tipe bangkitan: parsial & 8 & 7,7 \\
Umum & 96 & 92,3 \\
\hline
\end{tabular}

Tabel 2 Hasil analisis univariat

\begin{tabular}{|c|c|c|c|c|c|c|}
\hline \multirow{2}{*}{ Faktor prediktor } & \multicolumn{2}{|c|}{ Kekambuhan } & \multirow[b]{2}{*}{ Total } & \multirow[b]{2}{*}{$\mathbf{R R}$} & \multirow[b]{2}{*}{$95 \%$ CI } & \multirow[b]{2}{*}{$\mathbf{P}$} \\
\hline & Kambuh (\%) & Tidak (\%) & & & & \\
\hline \multicolumn{7}{|l|}{ Umur awitan: } \\
\hline - anak & 9 & 7 & 16 & 0,811 & $0,515-1,278$ & 0,228 \\
\hline - dewasa & 61 & 27 & 88 & & & \\
\hline \multicolumn{7}{|l|}{ Riwayat keluarga } \\
\hline - ada & 3 & - & 3 & 1,507 & $1,312-1,732$ & 0,549 \\
\hline - tidak ada & 67 & 34 & 101 & & & \\
\hline \multicolumn{7}{|l|}{ Riwayat kej.demam: } \\
\hline - ada & 13 & 4 & 17 & 1,167 & $0,861-1,583$ & 0,573 \\
\hline - tidak ada & 57 & 30 & 87 & & & \\
\hline \multicolumn{7}{|l|}{ Jenis bangkitan: } \\
\hline - parsial & 6 & 2 & 8 & 0,889 & $0,852-1,359$ & 1,000 \\
\hline - umum & 64 & 32 & 96 & & & \\
\hline \multicolumn{7}{|l|}{ Etiologi: } \\
\hline - idiopatik & 53 & 21 & 74 & 1,264 & $0,896-1,783$ & 0,169 \\
\hline - simptomatik & 17 & 13 & 30 & & & \\
\hline \multicolumn{7}{|l|}{ Gambaran EEG: } \\
\hline - normal & $18(42,9)$ & $24(57,1)$ & 42 & 1,957 & $1,357-2,822$ & 0,000 \\
\hline - abnormal & $52(83,9)$ & $10(16,1)$ & 62 & & & \\
\hline
\end{tabular}

Berdasarkan tabel.1, Subjek laki-laki sebanyak 54 orang $(51,9 \%)$ dibandingkan perempuan 50 orang $(48,1 \%)$, dengan rerata umur awitan adalah 24,5 tahun. Pada penelitian ini didapatkan $71,2 \%$ dengan penyebab yang idiopatik sedangkan dengan penyebab yang simptomatik terdapat $28,8 \%$ subjek. Terdapat 70 orang subjek $(67,3 \%)$ yang mengalami kekambuhan. Penderita dengan riwayat kejang demam hanya didapatkan 17 orang $(16,3 \%)$, hal ini mungkin kejang demam yang terjadi berupa kejang demam kompleks, di mana kecenderungan menjadi epilepsi sangat tinggi (30\% sampai 50\%). Penderita epilepsi dengan riwayat keluarga epilepsi hanya terdapat 3 orang (2,9\%). Tipe bangkitan terbanyak pada subjek adalah tonik klonik umum terdapat pad 96 subjek (75\%).

Berdasarkan tabel 2, faktor umur awitan, riwayat keluarga, riwayat kejang demam, jenis bangkitan, dan etiologi tidak bermakna sebagai faktor prediktor kekambuhan bangkitan epilepsi dengan tingkat kemaknaan $\mathrm{p}>0,05$, sedangkan EEG cukup bermakna sebagai prediktor prognosis kekambuhan dengan $\mathrm{p}<0,05$.
Subjek dengan riwayat kejang demam dalam penelitian ini berpeluang mengalami kekambuhan sebesar 1,167 kali dengan nilai kemaknaan sebesar $\mathrm{p}=0,57$. Walaupun secara statistik tidak bermakna, pada kejang demam kompleks risiko menjadi epilepsi meningkat sebesar 7,6 kali dibanding kejang demam sederhana $(\mathrm{p}<0,01)$, mungkin hal ini dapat disebabkan bahwa kejang demam kompleks akan mengakibatkan kerusakan DNA dan protein otak sehingga menimbulkan jaringan parut dan inilah mengakibatkan terganggunya proses inhibisi dan kejang berkepanjangan akan menyebabkan sklerosis pada jaringan otak dan terbentuklan fokus epilepsi atau discharge epileptiform (Maytal et al, 1989).

Bangkitan epilepsi didasari oleh suatu discharge epileptiform, di mana hal ini tampak dari gambaran EEG yang abnormal. Aktivitas epileptiform EEG lebih spesifik dalam mengetahui abnormalitas irama otak, dan ini dapat sebagai indikasi lokasi stuktur otak yang patologi yang mendasari suatu bangkitan, atau disfungsi kortikal difus pada epilepsi umum yang simptomatik (Smith, 2005). 
Terdapat beberapa karakteristik kejang demam yang dapat berkembang pada kejang berikutnya atau menjadi epilepsi antara lain: a) sebelum demam yang pertama sudah ada kelainan neurologi atau gangguan tumbuh kembang, b) ada riwayat kejang demam pada orang tua atau saudara kandungnya, c) kejang demam fokal, lebih dari 15 menit atau berkali-kali dalam sehari (Bromfield, 2002).

Frekuensi terbanyak pada tipe tonik klonik umum, sesuai dengan penelitian Fukushima (1981) yang menyatakan bahwa kekambuhan banyak dijumpai pada epilepsi tipe umum, hal ini mungkin akibat adanya epileptiform discharge yang sinkron bilateral dan simetris mengenai kedua hemisfer (Kilpatrick CJ. 2004). Bangkitan tipe mioklonik, bangkitan tonik klonik dan parsial berkaitan dengan peningkatan risiko bangkitan berulang yang mengikuti penghentian obat (Leary et al, 1999).

Umur awitan anak-anak didapatkan RR: 0,811 (95\% CI: 0,515-1,278; $\mathrm{p}=0,228)$, berbeda dengan penelitian sebelumnya yang menyatakan terdapat hubungan yang menyolok antara usia yang awal dari onset bangkitan dan risiko peningkatan kekambuhan ketika terapi dihentikan $(\mathrm{p}<0,02)$ (Emerson et al, 1981), sedangkan Berg \& Shinnar (1994) dalam suatu meta-analisis menyatakan hanya sedikit peningkatan risiko kekambuhan pada umur awitan dewasa dibanding anak-anak.

Subjek dengan riwayat kejang demam dalam penelitian ini berpeluang mengalami kekambuhan sebesar 1,167 kali dengan nilai kemaknaan sebesar $p=0,57$. Walaupun secara statististik tidak bermakna, pada kejang demam kompleks risiko menjadi epilepsi meningkat sebesar 7,6 kali dibanding kejang demam sederhana $(p<0,01)$, mungkin hal ini dapat disebabkan bahwa kejang demam kompleks akan mengakibatkan kerusakan DNA dan protein otak sehingga menimbulkan jaringan parut dan inilah mengakibatkan terganggunya proses inhibisi dan kejang berkepanjangan akan menyebabkan sklerosis pada jaringan otak dan terbentuklan fokus epilepsi atau discharge epileptiform (Maytal et al, 1989).

Dalam suatu meta-analisis yang dilaporkan Berg dan Shinnar (1994), terdapat hubungan antara EEG yang abnormal dengan peningkatan risiko kekambuhan bangkitan pada anak dan dewasa, dengan risiko relatif 1,45. Pada penelitian ini, terbukti bahwa gambaran EEG cukup bermakna sebagai prediktor kekambuhan pada penderita epilepsi yang teratur berobat $(\mathrm{P}<$ $0,05)$. Risiko relatif yang didapat yaitu 1,957 (95\% CI, 1,357-2,822) menunjukkan bahwa terjadinya kekambuhan pada penderita epilepsi dengan gambaran EEG abnormal sebesar 1,957 kali dibandingkan yang dengan EEG normal. Kilpatrick (2004) menyatakan penelitian yang dilakukan MRC (Medical Research Council) menemukan bahwa pasien dengan bangkitan tonik klonik dan gambaran EEG generalised spike wave mempunyai angka kekambuhan yang tinggi.

Bangkitan epilepsi didasari oleh suatu discharge epileptiform, di mana hal ini tampak dari gambaran EEG yang abnormal. Aktivitas epileptiform EEG lebih spesifik dalam mengetahui abnormalitas irama otak, dan ini dapat sebagai indikasi lokasi stuktur otak yang patologi yang mendasari suatu bangkitan, atau disfungsi kortikal difus pada epilepsi umum yang simptomatik (Smith, 2005).

\section{SIMPULAN}

EEG cukup bermakna dalam memprediksikan kekambuhan dengan risiko relatif sebesar $1,957 \quad(95 \%$ CI, 1,357-2,822) yang berarti penderita epilepsi dengan gambaran EEG yang abnormal pada awal pengobatan akan mendapatkan peluang yang lebih besar terjadi kekambuhan setelah mengalami remisi.

\section{DAFTAR PUSTAKA}

Andersson T., Braathen G., Person A., Theorell K. 1997. A Comparison Between One and Three Years of Treatment in Uncomplicated Childhood Epilepsy: A Prospective Study. The EEG as Predictor of Outcome after Withdrawal of Treatment, Epilepsia, 38(2): 225-232.

Berg AT., Shinnar S. 1994. Relapse Following Discontinuation of Antiepileptic Drugs; a Meta-analysis. Neurology; 44 : 601-608.

Bromfield EB. 2002. Epileptiform Discharge, eMedicine World Medical Library 
Dreifuss FE. 1994. Prognosis of Childhood Seizure Disorders: Present and Future, Epilepsia, 35 (suppl 2) $\mathrm{s} 30-\mathrm{s} 34$.

Emerson RD., Souza B., Vinning E. 1981. Stopping Medication in Children with Epilepsy. Predictor of Outcome. N Engl J Med; 304: 1125-1129.

Kaiser C., Benninger C., Asaba G., Mugisa C. 1998. Clinical and Electro Clinical Classification of Epileptic Seizure in West Uganda, $3^{\text {rd }}$ Congress of Tropical Neurology, 30 November-2 Desember 1998.

Kilpatrick CJ. 2004. Withdrawal of Antiepileptic Drugs in Seizure-free Adults, Australian Prescriber, vol.27, No.5:114-117.

Lamdhade SJ., Taori GM. 2002. Study of Responsible for Recurrence of Seizures in Controlled Epileptics for more than 1,5 years after Withdrawal of Antiepileptic Drugs, Neurology India; 50: 295-300.

Leary PM., Riordan G., Sceleigei B., Morris S. 1999. Childhood Secondary (Symptomatic) Epilepsy Seizure Control, and Intelectual Handicap in a Notropical Region of South Africa, Epilepsia, 40(8); 1110-13.

Mardjono M, 1996. Majalah Kedokteran Indonesia, volume: 46, Nomor: 8, Agustus.

Maytal J., Shinar S., Moshe SL., Alvarez LA. 1989. Law morbidity and mortality of Status Epilepticus in Children, Pediatric 83; 323-331.

Sacket DL, 2001. Evidence Based Medicine: How to Practice and Teach EBM, Oxford University Press.

Smith SJM, 2005. EEG in The Diagnosis, Classification, and Management of Patient with Epilepsy, $J$ Neurol Neurosurg Psychiatry; 76 (Suppl III): ii2-ii7

Sundaram M., Sadler RM., Young GB., Pillay N. 1999. EEG in Epilepsy: Current Perspectives, Canadian Journal of Neurological Sciences; 26: 255- 62.

WHR 2001. Epilepsy in the World Report, Mental Health: New Understanding, New Hope, WHO. 